\title{
SAXIFRAGA MINUTISSIMA, A NEW SPECIES FROM THE GARHWAL HIMALAYA, INDIA, AND ITS IMPLICATIONS FOR THE TAXONOMYOF THE GENUS SAXIFRAGA (SAXIFRAGACEAE)
}

\author{
R. J. Gornall ${ }^{1}$, D. S. Rawat ${ }^{2} \& Z_{\text {HuOXIN }} Z_{H A N G}{ }^{1}$
}

\begin{abstract}
Saxifraga minutissima D.S.Rawat, a new and extremely small species of Saxifraga (Saxifragaceae), is described from the Garhwal Himalaya, India. It differs from all other species of Saxifraga, except Saxifraga bicuspidata, in having five stamens and lacking petals. It can be distinguished from Saxifraga bicuspidata in having leaves and sepals entire. The finely striate pollen exine pattern of Saxifraga minutissima indicates that the species belongs to Saxifraga section Ciliatae. Its prostrate, axillary leafy shoots and lack of crisped, rufous hairs strongly suggests a place in Saxifraga subsection Serpyllifoliae, where one of its closest relatives may be Saxifraga stella-aurea.
\end{abstract}

Keywords. Pollen, Saxifraga minutissima, Saxifraga section Ciliatae subsection Serpyllifoliae, Saxifragaceae, Saxifragella, seeds.

\section{INTRODUCTION}

Routine floristic surveys have been conducted by one of the authors (D.S.R.) in alpine zones of the Garhwal Himalaya over the last two decades. During these surveys, a remarkable new species belonging to Saxifraga section Ciliatae Haw. was discovered, and is described and illustrated here with notes on its habitat and discussion of its taxonomic relationships. The species is discussed in the context of the classification by Gornall (1987).

\section{Species Description}

Saxifraga minutissima D.S.Rawat, sp. nov. Figs 1, 2.

A congeneribus omnibus differt, praeter Saxifraga bicuspidata Hook.f., floribus apetalis et staminibus 5(-6). A Saxifraga bicuspidata foliis et sepalis integris differt. Species habitu cum Saxifraga stella-aurea Hook.f. \& Thomson optime congruens, sed differt statura perpusilla. - Type: India, Garhwal Himalaya,

\footnotetext{
${ }^{1}$ Department of Biology, University of Leicester, Leicester LE1 7RH, UK. E-mail for correspondence: rjg@le.ac.uk

2 Department of Biological Sciences, College of Basic Sciences and Humanities, G.B. Pant University of Agriculture and Technology, Pantnagar 263 145, Uttarakhand, India.
} 


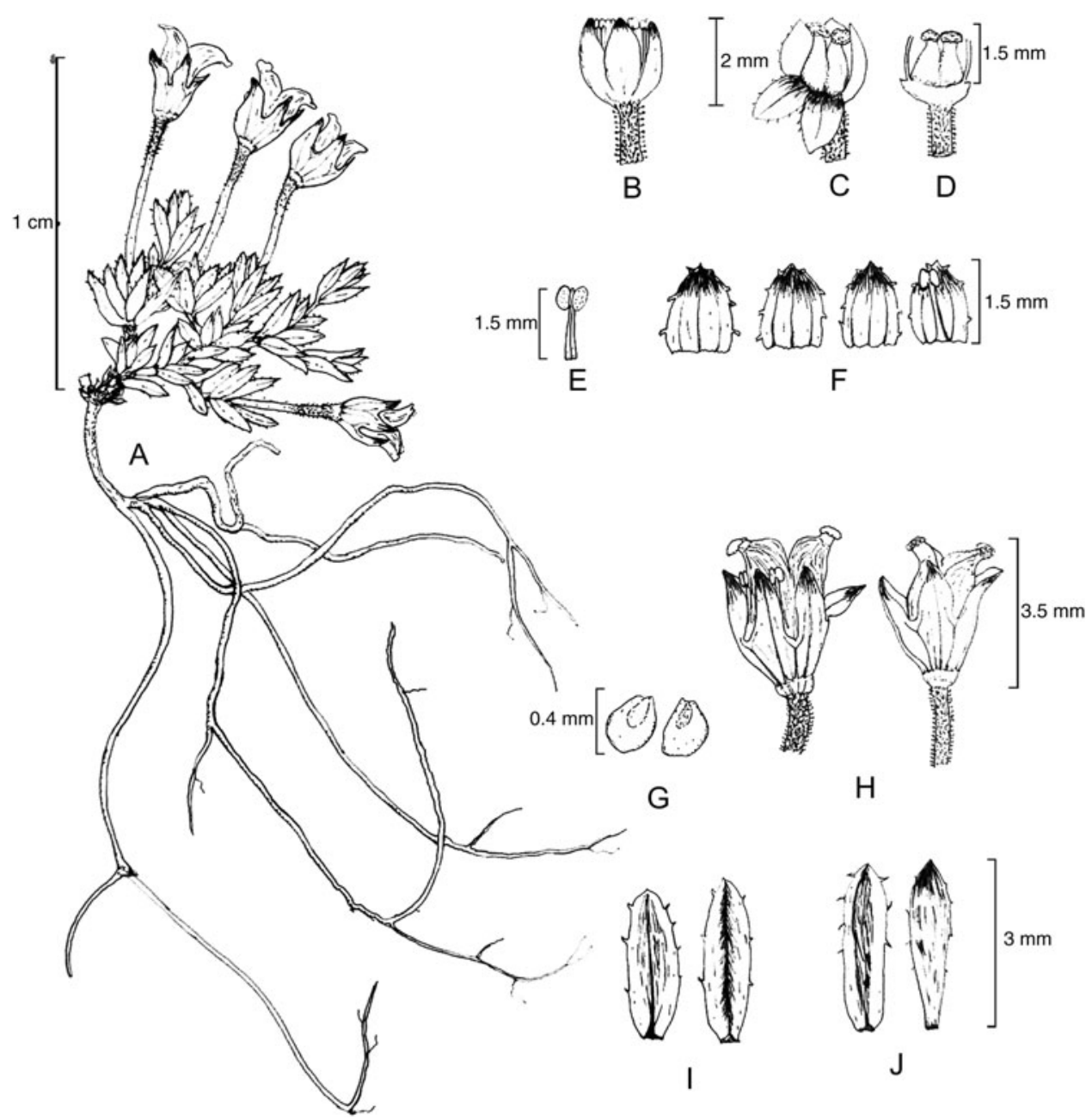

FIg. 1. Saxifraga minutissima D.S.Rawat, sp. nov. A, whole plant; B, flower; C-D, dissected flowers showing carpel and stamens; E, stamen; F, sepals, one showing antesepalous stamen; G, seeds; H, mature carpel; I, leaves from basal rosette; J, leaves from vegetative shoots. Drawn by Dharmendra S. Rawat.

Rudraprayag District, Vasuki Tal area near Kedarnath, in alpine zones with mosses, $4600-4800 \mathrm{~m}$ a.s.1., $30^{\circ} 44^{\prime} 27^{\prime \prime} \mathrm{N}, 7^{\circ} 01^{\prime} 25^{\prime \prime} \mathrm{E}, 10$ ix 2001 , D.S. Rawat GBPUH Acc. No. 442 (holo GBPUH (G.B. Pant University Herbarium, Pantnagar, Uttarakhand, India); iso BM).

Perennial herb, $8-13 \mathrm{~mm}$ tall, branched at base to form loose cushions up to $5 \mathrm{~cm}$ across. Proximal axillary shoots leafy, prostrate, with small, distal leaf rosettes. Rosette leaves sessile, linear to oblong-lanceolate, margin entire, glabrous or rarely with eglandular hairs, apex acute or obtuse, adaxial surface sometimes with 

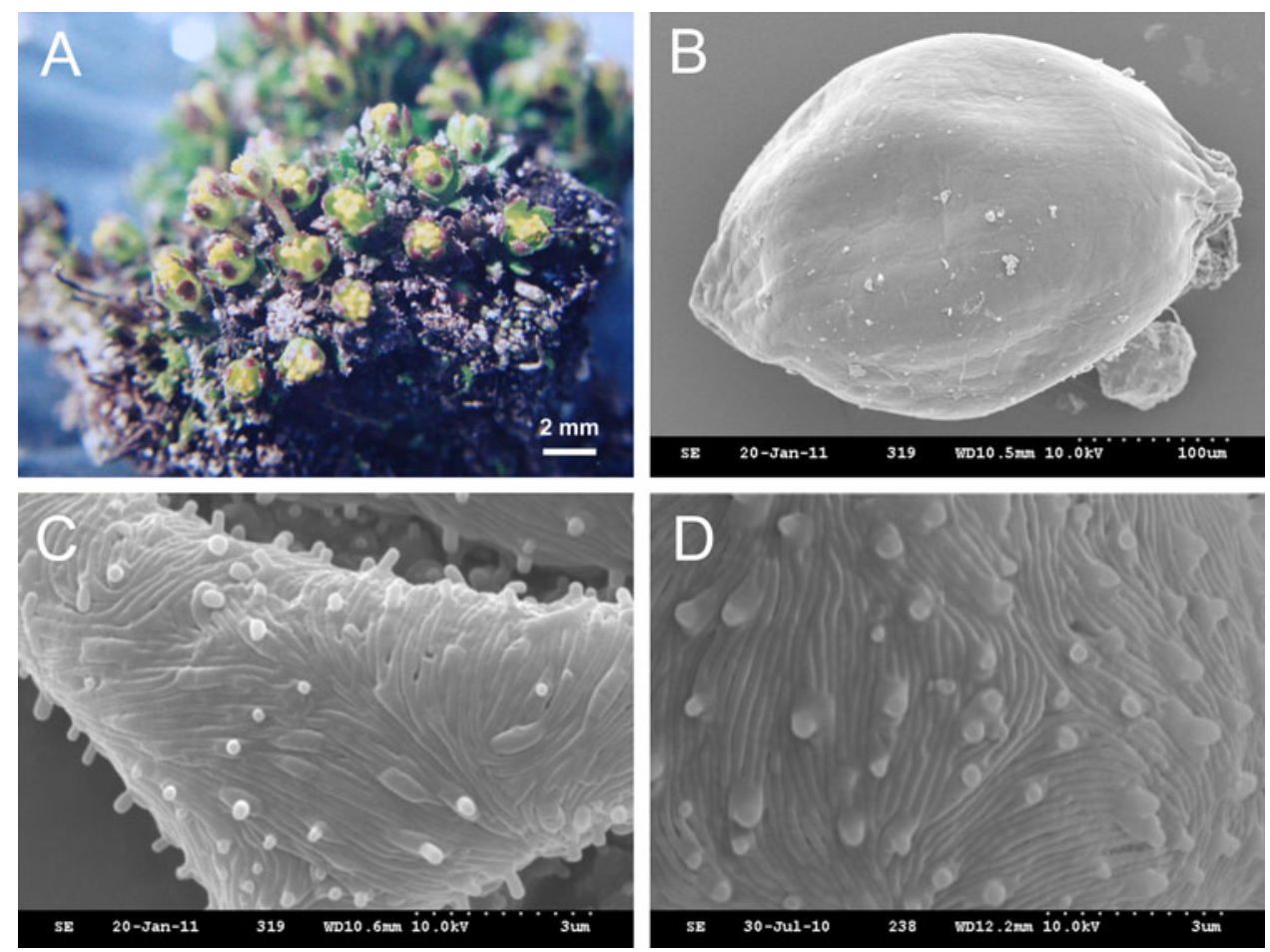

Fig. 2. A, Saxifraga minutissima growing with mosses; B, seed of S. minutissima showing its smooth surface; C, pollen exine of $S$. minutissima showing the finely striate pattern characteristic of section Ciliatae; D, pollen exine of $S$. stella-aurea, a putatively related species (Table 1).

eglandular hairs, $1.5-2.5 \times 0.5-1 \mathrm{~mm}$. Horizontal stem leaves sessile, linear to oblong-lanceolate, margin entire, glabrous or rarely with eglandular hairs, apex acute or obtuse, surface glabrous, $1.5-2 \times 0.5 \mathrm{~mm}$, somewhat fleshy. Flowering stem terminal, leafless, without bracts. Flowers solitary; pedicel (1-)3-6 mm, with brownglandular hairs. Sepals 5, erect, 1-1.2 $\times 0.6-1 \mathrm{~mm}$, ovate to oblong, apex reddish, acute or subacute, adaxial surface and margins glabrous, or rarely with a few brownglandular hairs; veins 3, confluent. Petals 0 . Stamens 5, rarely 6 (seen in only one out of 26 flowers dissected), antesepalous, equalling sepals, filaments linear, c. $0.7 \mathrm{~mm}$, the dehisced anthers c. $0.3 \mathrm{~mm}$, yellow, thecae parallel on dehiscence. Ovary semiinferior at anthesis, ovoid to oblong, to $2.5 \mathrm{~mm}$ long in fruit; carpels tapered to short conical styles, styles $0.2-0.3 \mathrm{~mm}$ long, exceeding sepals, stigmas capitate. Seeds spherical to ovoid, shining brown, smooth, $0.3-0.4 \mathrm{~mm}$.

Distribution. Saxifraga minutissima is restricted to a small area of the Garhwal Himalaya. Only two populations are currently known: one from the Vasuki Tal area, where the type was collected, and the other from 4-5 km away in Madhuganga Valley, also near Kedarnath. Specimens from the second locality are suitable 
paratypes: India, Garhwal Himalaya, Rudraprayag District, Madhuganga Valley near Kedarnath, 4200-4500 m, 24 viii 2005, D.S. Rawat (BM); ibid., 4 x 2007, D.S. Rawat (BM).

Ecology. The plant is very small, scarcely more than $1 \mathrm{~cm}$ tall, forming loose cushions reaching up to $5 \mathrm{~cm}$ in diameter. It grows in moist sandy places on scree slopes or along streams. Its immediate associates are mosses, from which to the casual observer it is scarcely distinguishable in its vegetative state. At both of its localities the species inhabits the higher alpine zone, being found at altitudes of 4600-4800 $\mathrm{m}$ in Vasuki Tal and slightly lower, 4200-4500 m, in the Madhuganga Valley (Fig. 3).

Phenology. Flowering: July-September; fruiting: September-October.

Conservation status. Data Deficient (apparently rare).

Etymology. The specific epithet refers to the impressively small size of the plants; the species is among the smallest known saxifrages.

Taxonomic relationships. The new species is assigned to Saxifraga on account of its alternate, exstipulate leaves, and flowers with five sepals, absence of a free hypanthium, presence of two carpels, and axile placentation. Its pollen exine is characterised by fine parallel lirae with granular supratectal processes or verrucae (Fig. 2C), a pattern that is a synapomorphy for Saxifraga section Ciliatae, for example S. stella-aurea (Fig. 2D) (Ferguson \& Webb, 1970; Kaplan, 1981). The monophyletic status of the section also has statistically significant support from ITS sequence data (Zhang et al., 2008). Within Saxifraga section Ciliatae, the presence in the new species of somewhat fleshy leaves and prostrate axillary leafy shoots, and the absence of rosette leaves and rufous, crisped hairs, indicates a position in subsection Serpyllifoliae (Gornall, 1987). Within that subsection, the only other very tiny species,
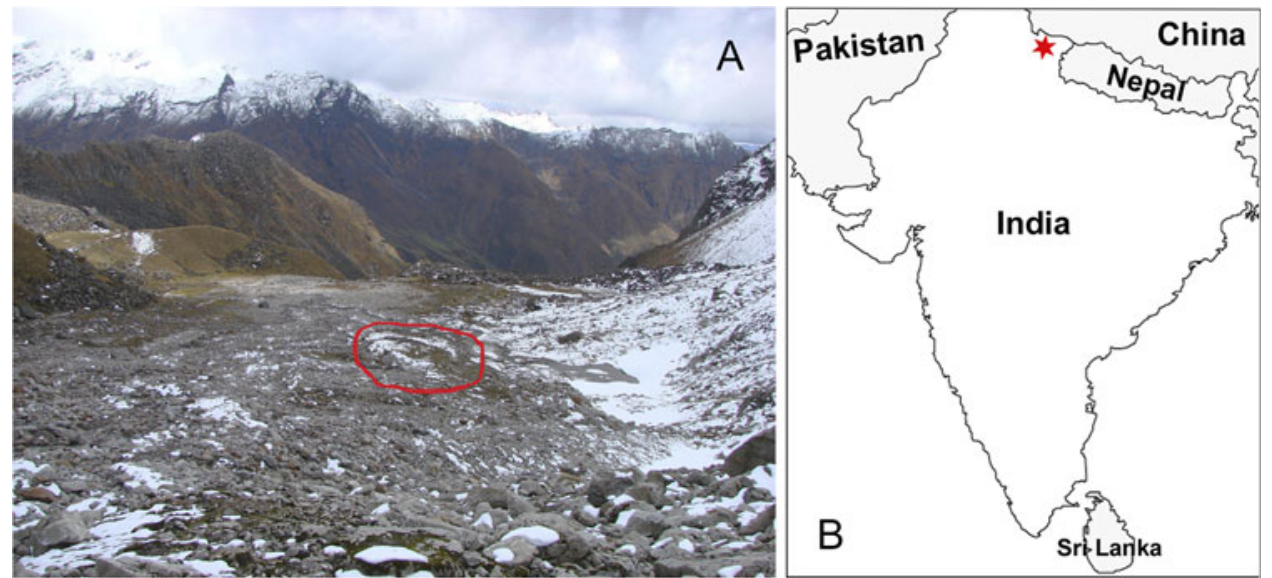

FIG. 3. Habitat (A) of Saxifraga minutissima (marked by a ring) in the Madhuganga Valley, Garhwal Himalaya (B, marked by a star), India. 
T A в LE 1. Main morphological differences between Saxifraga minutissima and its closest putative relatives in section Ciliatae subsection Serpyllifoliae and S. bicuspidata

\begin{tabular}{|c|c|c|c|c|c|}
\hline Species & Basal leaves & Pedicel hairs & Sepals & Petals & $\begin{array}{l}\text { Stamen } \\
\text { number }\end{array}$ \\
\hline S. minutissima & $\begin{array}{l}\text { Linear to oblanceolate, } 1.5-2.5 \times 0.5-1 \mathrm{~mm} \text {, } \\
\text { apex acute to obtuse, adaxial surface and } \\
\text { margin glabrous or rarely with eglandular } \\
\text { hairs }\end{array}$ & $\begin{array}{l}\text { Brown-glandular } \\
\text { pubescent }\end{array}$ & $\begin{array}{l}\text { Erect, apex acute } \\
\quad \text { to subacute }\end{array}$ & Absent & 5 \\
\hline S. inconspicua & $\begin{array}{l}\text { Elliptic, } 1.5-3 \times 0.3-1 \mathrm{~mm} \text {, apex obtuse, } \\
\text { glabrous }\end{array}$ & Glabrous & Erect, apex obtuse & $\begin{array}{l}\text { Present, } 1.5 \times \\
0.6-0.7 \mathrm{~mm}\end{array}$ & 10 \\
\hline S. stella-aurea & $\begin{array}{l}\text { Ovate to elliptic, } 2-5 \times 1-2 \mathrm{~mm} \text {, apex obtuse, } \\
\text { margin brown-glandular hairy, adaxial } \\
\text { surface glabrous }\end{array}$ & $\begin{array}{l}\text { Brown-glandular } \\
\text { pubescent }\end{array}$ & $\begin{array}{l}\text { Reflexed, apex } \\
\text { acute to obtuse }\end{array}$ & $\begin{array}{c}\text { Present, } 4-7 \times \\
1.5-3.4 \mathrm{~mm}\end{array}$ & 10 \\
\hline S. bicuspidata & $\begin{array}{l}\text { Linear-spathulate, }(2.5-) 3-5(-7.5) \times 0.7-1.4 \mathrm{~mm} \text {, } \\
\text { apex deeply emarginate with acute sinus, } \\
\text { glabrous }\end{array}$ & Glabrous & $\begin{array}{l}\text { Erect, apex deeply } \\
\text { emarginate }\end{array}$ & Absent & 5 \\
\hline
\end{tabular}


which may be related, are Saxifraga stella-aurea and S. inconspicua W.W.Sm. These differ from our new species as outlined in Table 1.

\section{DISCUSSION}

The striking features of the plant are the lack of petals (instead of five) and the presence of only five stamens (instead of eight or the more usual ten), with the antepetalous whorl missing. The genus Saxifraga contains some 450 species, which display a remarkably constant floral morphology, viz. pentamerous, diplostemonous, bicarpellate flowers with axile placentation and lacking a free hypanthium. Deviations from this combination of characters are remarkably few but include a small group of species belonging to subsection Kabschia which possess tetramerous flowers with eight stamens. The occurrence of only five stamens is found otherwise

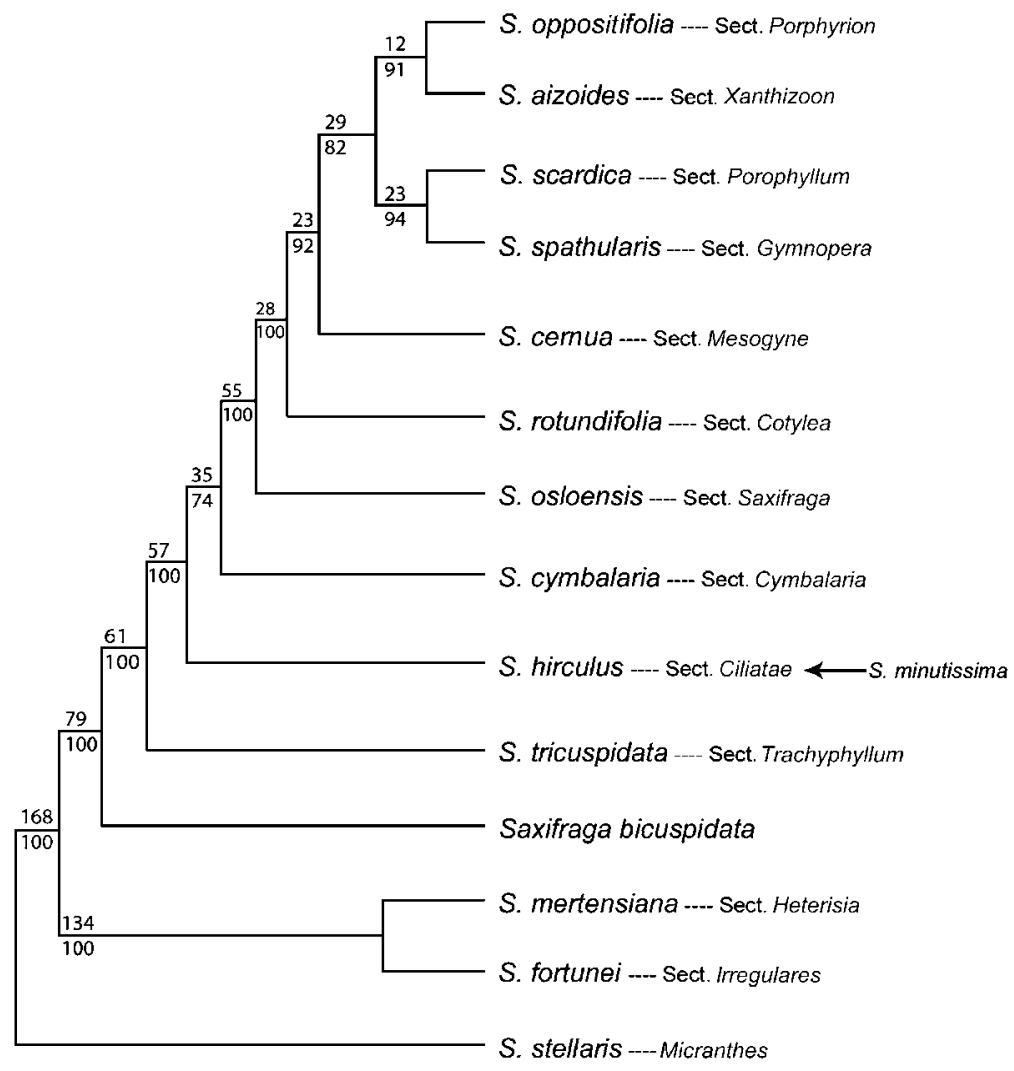

FIg. 4. Phylogenetic tree of Saxifraga, redrawn from the six-gene analysis by Soltis et al. (2001). Percentages below branches are bootstrap values; numbers above branches are the number of base substitutions. The figure shows the position of Saxifraga bicuspidata and the putative position of $S$. minutissima (indicated by an arrow) inferred from the pollen synapomorphy it shares with section Ciliatae. 
only in Saxifraga bicuspidata (Table 1), in which they are also antesepalous and which, interestingly, is similarly apetalous (Moore, 1983). Apetaly is found in two other species, namely Saxifraga eschscholtzii Cham. ex DC. (Saxifraga section Ciliatae subsection Hemisphaericae), and S. cespitosa f. apetala Engl. (Saxifraga section Saxifraga series Caespitosae). Saxifraga bicuspidata comes from the southern tip of South America, in an area around Tierra del Fuego. Although it was originally assigned to Saxifraga (Hooker, 1846), it was soon segregated as the monotypic genus Saxifragella (Engler, 1891), on account of the reduced stamen number. This arrangement has been accepted by botanists ever since (Moore, 1969), that is until Soltis et al. (2001) demonstrated by means of a phylogenetic analysis of six DNA regions (four chloroplast and two nuclear sequences) that the species was nested within Saxifraga, albeit near the base alongside species of Saxifraga section Irregulares (which have uniquely zygomorphic corollas) and S. mertensiana Bong. (Fig. 4).

Any notion of increasing the homogeneity of Saxifraga by redrawing its boundaries to exclude these basal groups clearly now has much less appeal. If our sectional assignment of the haplostemonous, apetalous Saxifraga minutissima is phylogenetically correct, then it is nested so deeply in the genus (Soltis et al., 2001; Zhang et al., 2008) that we must accept that Saxifraga, on occasion, may lack petals and may even have as few as five stamens. It seems probable that the very rare (for Saxifraga) mutations causing apetaly and five stamens in both the Himalayan Saxifraga minutissima and the Fuegian S. bicuspidata are the result of parallel evolution.

\section{REFERENCES}

Engler, [H. G.] A. (1891). Saxifragaceae. In: Engler, A. \& Prantl, K. (eds) Die natürlichen Pflanzenfamilien, pp. 41-93. Leipzig: W. Engelmann.

Ferguson, I. K. \& We в , D. A. (1970). Pollen morphology in the genus Saxifraga and its taxonomic significance. Bot. J. Linn. Soc. 63(4): 295-311.

Gornall, R. J. (1987). An outline of a revised classification of Saxifraga L. Bot. J. Linn. Soc. 95(4): 273-292.

Hooker, J. D. (1846). The Botany of the Antarctic Voyage. London: Reeve Bros.

KAPLAN, K. (1981). Embryologische, pollen- und samenmorphologische Untersuchungen zur Systematik von Saxifraga (Saxifragaceae). Bibl. Bot. 134: 1-56, tt.26.

Moore, D. M. (1969). Saxifragodes, a new genus of Saxifragaceae from Tierra del Fuego. Bot. Not. 122: 322-329.

Moore, D. M. (1983). Flora of Tierra del Fuego. St Louis, MO: Missouri Botanical Garden.

Soltis, D. E., Kuzoff, R. K., Mort, M. E., Zanis, M., Fishbein, M., Hufford, L., Koontz, J. \& Arroyo, M. K. (2001). Elucidating deep-level phylogenetic relationships in Saxifragaceae using sequences for six chloroplastic and nuclear DNA regions. Ann. Missouri Bot. Gard. 88(4): 669-693.

Zhang, D. J., Chen, S. Y., Gao, Q. B., Duan, Y. Z. \& Chen, S. L. (2008). Circumscription and phylogeny of Saxifraga sect. Ciliatae: Evidence from nrDNA ITS sequences. J. Syst. Evol. 46(5): 667-675. 